\title{
VESELĪBAS APRŪPE LATVIJĀ: KĀDA IR ĢEOGRĀFIJAS IETEKME UZ DIASPORAS IZVĒLI?
}

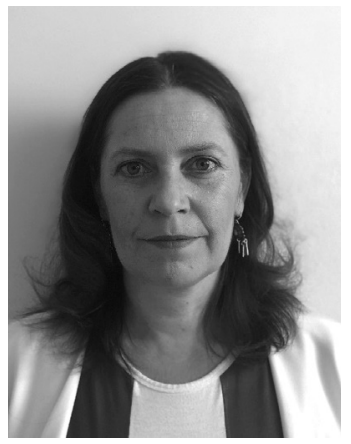

Ieva Reine, Dr. med., Mg. psych., Mg. sc. sal., ir Zviedrijas Sociālās apdrošināšanas aǵentūras sociālās apdrošināšanas eksperte un analīitịe. Kopš doktora grāda iegūšanas sociālajā medicīnā un dzimtes studijās Ūmeo (Umeå) Universitātē Zviedrijā galvenokārt pētījusi cilvēku ar smagu invaliditāti labklājības un sociālās apdrošināšanas jautājumus. Bijusi arī ilggadēja asociētā pētniece Upsalas (Uppsala) Universitātē, kur darbojusies par projekta vadītāju, vadošā pētniece un turpina lasīt lekcijas un vada maǵistrantūras un doktorantūras studentu darbus. Iepriekšějie pētījumi ir bijuši saistīiti ar dažādiem sabiedrības veselības aspektiem, piem., psihisko veselību un bezdarbnieku veselības uzvedības paradumiem pārejas posmā no pusaudža vecuma līdz brieduma gadiem, kā arī ar invaliditāti un labklājīibu, sociālās apdrošināšanas un drošības sistēmām, īpašu uzsvaru liekot uz dzimtes mijiedarbību ar individuāliem, sociāliem un strukturāliem faktoriem. Jaunākās profesionālās un pētniecības intereses ietver Eiropas sociālās apdrošināšanas sistēmu un tiesību aktu izpēti. Pašlaik ir Latvijas Universitātes Filozofijas un sociologiijas institūta un Rīgas Stradiņa universitātes vadošā pētniece, nesen uzsākusi vadīt projektu par sabiedrības novecošanas jautājumiem Baltijas jūras reǵiona valstīs. Vada arī Ziemeḷvalstu diasporas izglīīibas un kultūras grupu. Ir ievērojama pieredze dažādu diasporas organizāciju vadībā, kas ḷauj ar lielu izpratni atainot ārvalstīs dzīvojošo Latvijas valstspiederīgo dzīvesstāstus un pieredzes.

Raksturvārdi: migrācija, labklājība, sociālā apdrošināšana, ārstniecības pakalpojumi, transnacionālisms, sabiedrības veselība.

\section{Ievads}

Veselības aprūpes pieejamība ir nozīmīgs labklājības un drošības aspekts ikvienam cilvēkam neatkarīgi no dzimuma, vecuma, ienākumu līmeņa, saziņas valodas, izcelsmes valsts un pašreizējās mītnes zemes. Nesenajos Latvijas zinātnieku pētījumos ar veselības aprūpi un sociālo drošību saistītie jautājumi ir pakāpušies ārpus Latvijas dzīvojošo tautiešu interešu un rūpju hierarhijā $\bar{a}^{1}$. Jaunā Diasporas likuma rosinātas, arī Latvijas sabiedrībā notiek plašas diskusijas par jautājumiem, kas saistīti ar nodokḷa apmēru ārvalstīs nopelnītajām

1 Mierina 2019; Hazans 2016. pensijām un likuma ietekmi uz remigrāciju². Aktualizējot sociālās drošības tēmas, no tām neatdalāma ir veselíbas aprūpes problemātika - kādi pakalpojumi būs pieejami ārpus Latvijas dzīvojošajiem un kas par to maksās ${ }^{3}$. Savukārt Latvijas valstspiederīgajiem citviet pasaulē nozīmīga ir pakalpojumu kvalitāte, pieejamība u. c. aspekti, kas nereti nosaka arī to, vai notiks izvēle par labu remigrācijai vai, tieši otrādi, to kavēs. Pētījumā Labklājības un sociālās integrācijas izpēte likvīdās migrācijas kontekstā: longitudinālā pieeja ${ }^{4}$ (turpmāk -

2 Reine 2020

3 Diaspora turpmāk nevarēs sanemt Latvijas valsts apmaksātu veselības aprūpi (04.12.2017.). Pieejams: https://www.latviesi.at/diaspora-turpmak-nevares-sanemt-latvijas-valsts-apmaksatu-veselibas-aprupi/ (30.09.2020.).

4 Pētījumu finansē Latvijas Zinātnes padomes grants Nr. LZP-2018/1-0042. 
Pētījums) liela uzmanība ir pievērsta respondentu - Latvijas diasporas - zināšanām par Eiropas sociālo apdrošināšanu un tās izmantošanu migrantu veselības un psiholog̣iskās labklājīibas nodrošināšanā. Eiropas Savienības direktīvas paredz iespējas saṇemt veselības aprūpi citās valstīis ${ }^{5}$, tai skaitā Latvijā, tāpēc pētījumā tiek arī apskatīts, cik lielā mērā veselības aprūpes pakalpojumu saṇēmēji izmanto šīs direktīvas sniegtās iespējas vai, tieši pretēji - iespējas saṇemt Latvijas valsts vai pašu apmaksātus pakalpojumus. Pētījumā arī tiek analizēts, kādi ir Latvijas veselības pakalpojumu izmantošanas motīvi un kā notiek to apmaksa. Raksts sniedz ieskatu, kurās mītnes zemēs dzīvojošie Latvijas diasporas pārstāvji izvēlas saņemt veselības aprūpi Latvijā. Uzmanība ir pievērsta arī vajadzībām, kuras apmierināt izvēlas pārsvarā Latvijā, padziḷināti skaidrojot kvalitatīvo pētījumu rezultātus.

\section{Pētījuma metodolog̣ija}

Pētījuma aptauja veikta laikā no 2019. gada 24. septembra līdz 11. novembrim, izmantojot longitudinālu dizainu (t. i., aicinot aptaujā piedalīties tos, kuri bija atstājuši savu kontaktinformāciju iepriekšējā aptaujā), taču piesaistot arī jaunus respondentus, replicējot 2014. gadā veiktās aptaujas pētījuma dizainu un metodologiiju. Tāpat kā 2014. gadā, informācija par aptauju izplatīta ar diasporas mediju palīdzību, ievietojot informāciju ārvalstīs dzīvojošo Latvijas valstspiederīgo interneta grupās un vēstkopās, ar Latvijas institūciju, kas veic darbu ar diasporu, palīdzību (Ārlietu ministrija, Vides aizsardzības un reǵionālās attīstības ministrija, Izglītības un zinātnes ministrija, Latviešu valodas aǵentūra, Latvijas Investīciju un attīstības aǵentūra), kā arī izsūtot informāciju un lūdzot ar to dalīties 390 iepriekš identificētām latviešu vai Latvijas izcelsmes cilvēku organizācijām, grupām, biedrībām, kopām, draudzēm u. tml. Tika izvietoti informatīvie reklāmplakāti par aptauju Facebook, portālos Delfi.lv (latviešu un krievu valodā) un Press.lv, tāpat Draugiem.lv

5 Direktīva 2011/24/ES par pacientu tiesību piemērošanu pārrobežu veselības aprūpē (Directive 2011). aicinājumi saviem lietotājiem, kā arī veikta aktīva komunikācija LU pētnieku mājaslapās un sociālajos tīklos. Anketa, tāpat kā 2014. gadā, bija pieejama latviešu, krievu un angḷu valodā, un bija iespējams aizpildīt anketas garo vai īso variantu. Pretstatā 2014. gadam, kad 66\% respondentu izvēlējās pilno anketas versiju, šoreiz 67\% izvēlējās aizpildīt īsāko anketas versiju, kurā daḷa jautājumu (pēc rotācijas principa) netika uzdoti. Aptaujā piedalījās 7702 respondenti vecumā no 15 gadiem: 6242 ārvalstīs dzīvojošie (t. sk. 334 transnacionāļi, kas dzīvo vienlaikus Latvijā un ārzemēs) un 1460 remigranti. Aptaujas anketa un metodologija tika saskaņota ar Latvijas Universitātes Sociālo zinātṇu fakultātes Ētikas komisiju.

Datu iegūšanai tika izmantota interneta aptauja. Lai aptaujas datus varētu attiecināt uz visu Latvijas valstspiederīgo emigrantu kopumu, pētîjumā tika izstrādāta īpaša statistisko datu svaru metodologija, izmantojot OECD, Eurostat, Latvijas Republikas Pilsonības un migrācijas lietu pārvaldes un Lielbritānijas Centrālās statistikas pārvaldes datus un daudzfaktoru datu imputāciju. Arī šajā ziņojumā tiks izmantoti svērti dati, nodrošinot rezultātu vispārināšanas iespēju. Aptauju dati ir svaroti attiecībā pret četriem emigrantu sociāldemogrāfiskajiem faktoriem - dzimumu, vecumu, izglìtības līmeni un galveno valodu, papildus stratificējot visu paraugkopu pēc emigrantu mītnes valsts. Svaru piemērošanas rezultātā visu svarošanā izmantoto faktoru sadalījums paraugkopā kḷūst vienāds ar šo faktoru sadalījumu ǵenerālkopā. Šo faktoru ietekme uz piedalīšanās varbūtību aptaujā no datu analīzes viedokḷa tiek dzēsta, tādējādi būtiski palielinot aptaujas datu reprezentativitāti. Tomēr nav pamata uzskatīt, ka šie faktori aptaujā piedalīšanās varbūtîbu nosaka pilnībā. Šo varbūtību noteikti ietekmē arī virkne citu faktoru, kuri diemžēl nav iekḷauti svaru aprēḳinā, jo tie ir vai nu paši par sevi neizmērāmi (piem., konkrēta indivīda vispārējais atsaucības līmenis), vai arī to sadalījums ǵenerālkopā nav zināms. Līdz ar to mēs nevaram apgalvot, ka svarotie dati ir pilnībā reprezentatīvi. Tomēr domājams, ka atlikušās novirzes no reprezentativitātes nav daudz lielākas nekā parasti sastopamās nerespondences radītās novirzes no reprezentativitātes 
klasiskā gadījumizlasē" $\bar{e}^{6}$ Izmantoti svari "visai Latvijas diasporai", kuru metodika izstrādāta remigrantu aptaujai Atgriešanās Latvija ${ }^{7}$.

\section{Analīze}

Čandera diasporas definīcijā "ārpus savas dzimtenes izkliedēta nācijas daḷa, kas apzinās savu piederību izcelsmes valstij", dažādās citu valstu teritorijās dzīvojošie indivīdi, kuri ir piederīgi Latvijai, uztur kultūras, ekonomiskās un politiskās saiknes ar Latviju? . Mazāk tiek apskatīti veselības aprūpes un sociālie jautājumi, kuri arvien biežāk ierindojas prioritāšu augšgalā un ir spēcīgi faktori, kas ietekmē izvēli: vai nu remigrācija/repatriācija, vai tomēr dzīves un darba gaitu turpināšana ārpus Latvijas. Pētījumā ir ietvertas respondentu grupas, kuras izvēlējās atbildēt uz pilno aptauju vai kurām pēc jautājumu bloka rotācijas principa tika uzdoti jautājumi par veselības aprūpi. Pētījuma pirmajā solī no visiem 7702 respondentiem, izmantojot statistiskos svarus, tika izvēlētas grupas, kuras mīt 1) ārpus Latvijas, 2) lielākoties ārpus Latvijas vai 3) pārmainus Latvijā un ārzemēs, kopumā veidojot 6242 respondentu grupu. Analītiskā darba nākamajā solī tika atlasīti tie 1395 respondenti, kuri bija izvēlējušies saņemt veselības aprūpi Latvijā pēdējo piecu gadu laikā. Līdzīgi kā citos pētījumos, tai skaitā diasporas aptaujās, sieviešu īpatsvars $(n=793)$ ir lielāks nekā vīriešu $(n=602)$ dalībnieku skaits (1. attēls).

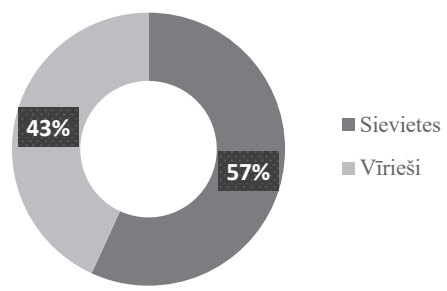

1. attēls. Respondentu dzimums, kuri mīt ārpus Latvijas, lielākoties ārpus Latvijas vai pārmaiṇus Latvijā un ārzemēs un kuri ir saṇēmuši veselības aprūpes pakalpojumus Latvijā pēdējo piecu gadu laikā

\footnotetext{
6 Goldmanis 2015.

Hazans 2016.

Chander 2001.

9 Dzenovska 2012, 176.
}

Pēc Pilsonības un migrācijas lietu pārvaldes (PMLP $)^{10}$ datiem, 2020. gada sākumā ārvalstīs savu dzīvesvietu bija reǵistrējuši 203933 Latvijas valstspiederīgie. Kā redzams 2. attēlā, tā augšgalā, pēc pētîjuma datos iegūtās informācijas par Latvijas veselības aprūpi saṇēmušo īpatsvara, ir Lielbritānija, arī Vācija, ASV un Îrija. Tomēr tās nav valstis, kurās mītošie Latvijas valstspiederīgie proporcionāli vairāk izmantotu iespējas saṇemt medicīnisko palīdzību. Savukārt tādas labklājības valstis kā Norvēǵija, Dānija, Austrija u. c. ir ierindojamas to valstu grupā, kurās mītošie Latvijas valstspiederīgie relatīivi vairāk izmanto Latvijas veselības aprūpes sniegtās iespējas nekā iepriekš minētajās valstīs, tomēr arī to rādītāji ir krietni zem vidējā. Savukārt tādas valstis kā Čehija, Islande, Malta, Polija ierindojas to valstu grupā, kur pieprasījums pēc veselības aprūpes Latvijā ir ievērojami augstāks nekā caurmērā. Arī Luksemburga ir ar augstāku Latvijas veselības aprūpes pakalpojumu izmantotāju īpatsvaru, ko varētu izskaidrot ar sociālās apdrošināšanas īpašajiem noteikumiem daḷai respondentu, kuri ir Eiropas Savienības institūciju darbinieki. Tomēr šāda sakarība nav atrodama Beḷgijāà dzīvojošajiem.

G̣eogrāfiskais tuvums tomēr neatspoguḷo tendenci saņemt veselības aprūpes pakalpojumus Latvijāa, jo rādītāji tādās tuvējās kaimiṇvalstīs kā Igaunija, Lietuva un Krievija tomēr ir krietni zem vidējā (1,5\%) visā iekḷauto valstu grupā. Kā bija paredzams, proporcionāli ārpus Latvijas dzīvojošo skaitam ASV, Kanādā, Austrālijā un Jaunzēlandē mītošie samērā nedaudz izmanto veselības aprūpes pakalpojumus Latvijā, kamēr uz visu valstu fona īpašu uzmanību izpelnās K̦ina ar vairāk nekā $12,9 \%$ veselības aprūpes pakalpojumu sañēmēju Latvijā.

Sākotnējie pētījuma rezultāti norāda, ka tieši veselības aprūpes (ne)pieejamība mītnes zemē un Latvijā var būt transnacionālismu veicinoša faktoru grupa. Individuālās izvēles atškiiras dažādās Eiropas valstīs mītošajiem, turklāt veselības aprūpes izmantošanas variācijas nereti ir kombinētas - gan kā medicīnas tūrisms, segts ar apdrošināšanu vai privāti, gan Latvijas valsts apmaksāta veselības aprūpe.

\footnotetext{
10 PMLP 2020.
} 

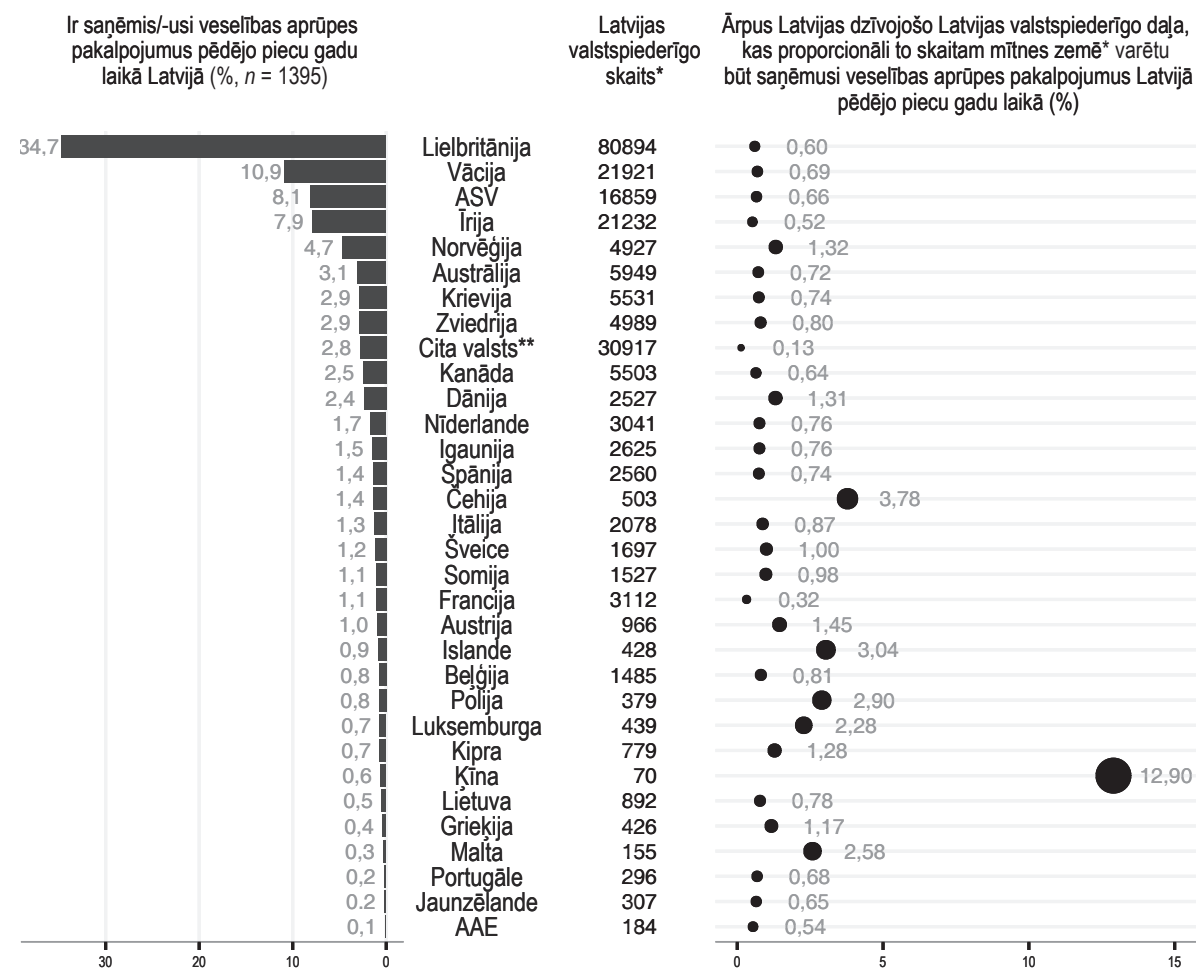

2. attēls. Valsts ārpus Latvijas, kurā respondents dzīvo un/vai strādā un saṇēmis veselības aprūpes pakalpojumus pēdējo 5 gadu laikā Latvijā, un kopējais ārpus Latvijas dzīvojošo tādu Latvijas valstspiederīgo skaits un attiecināmā proporcija, kuri saṇēmuši veselības aprūpes pakalpojumus Latvijā

Piezīmes: * - pēc PMLP 2020. gada sākuma datiem; ** - cita valsts ir jebkura valsts, kas nav iekḷauta tabulā. Vizualizācija: Aleksandrs Aleksandrovs

Kopumā 165 respondentiem bija iespēja atbildēt uz jautājumiem par problēmām saņemt veselības aprūpes pakalpojumus mītnes zemēs, proti, kas tieši vai netieši veicina braucienu intensitāti un ilgumu uz Latviju.

Jautājumu izvēle jau projekta plānošanas gaitā paredzēja kvantitatīvo datu izmantošanu par pamatu kvalitatīvo datu ieguvei, veicot intervijas, kas labāk l,autu izprast iegūtos statistiskos rezultātus. No pētījumā līdz šim veiktajām padzilinātajām intervijām ar dažādu Eiropas valstu respondentiem vairāki veselības aprūpes pakalpojumi mītnes zemēs tika vērtēti kā nepieejami/neeksistējoši vai nepietiekami labas kvalitātes. Visi aptaujātie respondenti atzina, ka Latvijā piedāvāto veselības pakalpojumu izmantošana un profilaktiskie izmeklējumi ir starp svarīgākajiem mērkiem, plānojot braucienus uz Latviju. Neraugoties uz respondentu pietiekamām mītnes zemes valodu un sistēmas zināšanām, tika pausta uzticēšanās savam Latvijas gimenes ārstam, pieejamām cenām profilaktiskiem izmeklējumiem un analīzēm, kurus daudzās labklājības valstīs neveic, kā ar̄̄ augsts Latvijas speciālistu novērtējums.

Visbiežāk mītnes zemēs neapmierinātība bija saistīta ar problēmām saņemt ārsta/ speciālista konsultāciju (3. attēls). Aptuveni puse respondentu no Vācijas, Lielbritānijas un vien nedaudz mazāk - no Nīderlandes bija saskārušies ar šīm problēmām. Intervijās aptaujātie atzina, ka Latvijā sañemt ārsta/speciālista pakalpojumus ir vieglāk, ātrāk un arī lētāk. Līdzịgi problēmas veikt izmeklējumus un analīzes mītnes zemēs visvairāk ir Vācijā dzīvojošajiem, kam seko İrija, Lielbritānija, Somija, Igaunija, Nīderlande, ASV u. c. (virs vidējā rādīiāja). Vācijā, Nīderlandē, Zviedrijā, 


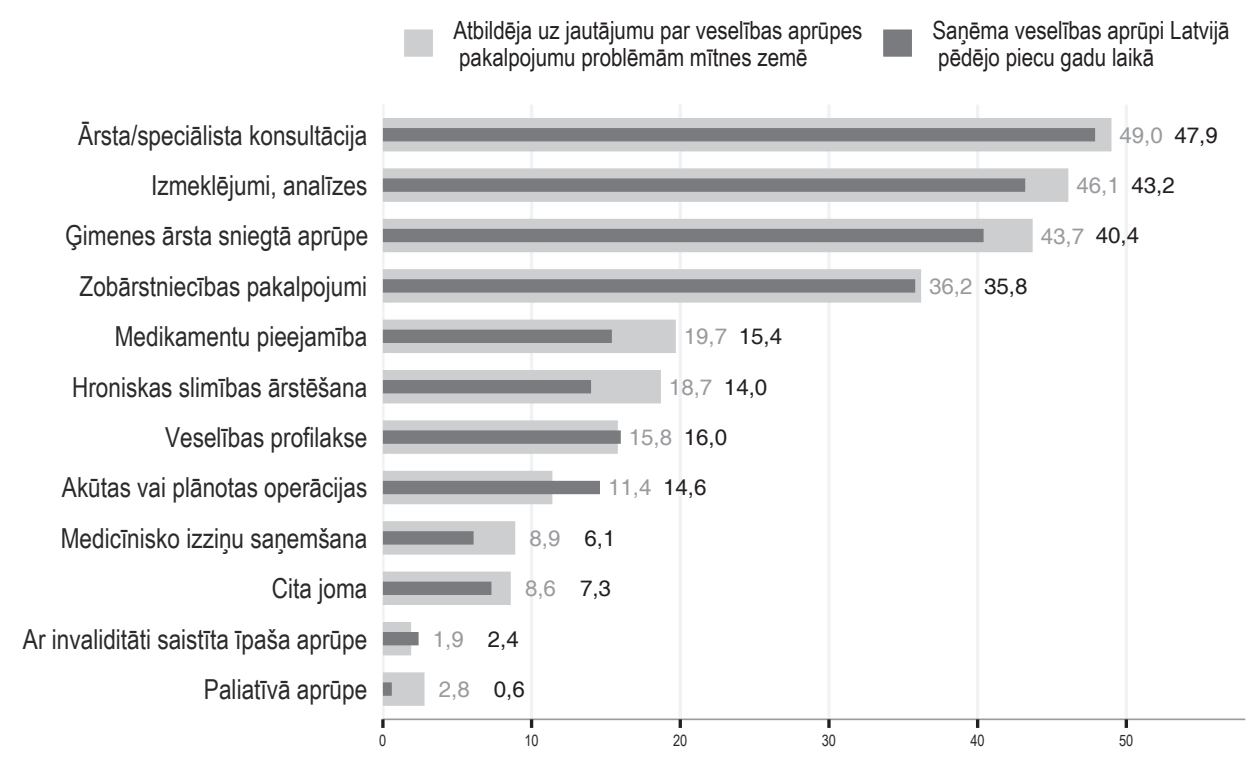

3. attēls. Kādā jomā respondents bija saskāries ar veselības aprūpes pakalpojumu problēmām mītnes zemē - visi kopā un atsevišķi tie respondenti, kuri saṇēmuši veselības aprūpi Latvijā pēdējo piecu gadu laikā

Vizualizācija: Aleksandrs Aleksandrovs

Lielbritānijā dzīvojošie vairāk nekā citi arī atzīmēja, ka ir grūtỉbas saṇemt ǵimenes ārsta pakalpojumus.

Nākamajā solī no tiem 364 respondentiem, kas kādu iemeslu dẹl nebija varējuši sañemt veselības aprūpes pakalpojumus savā mītnes zemē ārpus Latvijas, tika atlasīti tie, kuri pēdējo piecu gadu laikā bija saṇēmuši veselības aprūpi Latvijā $(n=165)$. Līdzīgi rezultāti caurmērā saglabājās arī šai izlasei.

Pētījumā ir objektīvs nepietiekamas informācijas daudzums, lai varētu izdarīt secinājumus par Ķīnā dzīvojošajiem Latvijas valstspiederīgajiem un viņu veselības aprūpes paradumiem un vajadzībām. Tiek izvirzīta hipotēze, ko nākamajos pētījumos, tai skaitā padziḷinātās intervijās, varētu pārbaudīt, vai valodas zināšanu trūkums, kā arī kulturālās atšķiiribas ir šķērslis, lai saṇemtu apmierinošus veselības aprūpes pakalpojumus tālajā valstî, ar kuru tiek veidotas arvien ciešākas biznesa un diplomātiskās saites. Iespējams, ne tikai Ķīnā, bet arī citās valstīs salīdzinoši nesen ieceḷojušajiem varētu būt nepietiekama sociālā un veselības apdrošināšana, lai pilnībā saṇemtu visus nepieciešamos pakalpojumus.
Šñ problemātika varētu būt attiecināma arī uz Eiropā strādājošajiem, kuri vēl nav ieklậauušies mītnes zemes sociālās drošības tīklā vai to nevar iegūt darba specifikas dēḷ.

Latvijas likumdevēji pēdējos gados ir pauduši ieinteresētību par ārpus Latvijas dzīvojošo nesamaksāto sociālo iemaksu apjomu, kas tomēr ḷauj tiem izmantot sistēmu bez maksas vai tikai ar pacienta iemaksu. Tāpēc viens no pētijuma mērkiiem bija noskaidrot, cik lielā mērā veselības aprūpes pakalpojumus apmaksā paši un cik - izmanto iespējas, ko sniedz Latvijas pilsonība, agrākais pieraksts pie ǵimenes ārsta, iespējams, ka kāds nav izdeklarējies u. tml.

Analizējot respondentu norādītos veselības aprūpes pakalpojumu apmaksas veidus, kopumā vien piektā dalıa (21\%) jeb 289 no 1376 respondentiem, kuri atbildēja uz jautājumu par apmaksas veidiem un kuri lielākā vai mazākā mērā dzīvo ārpus Latvijas, pilnībā izmantoja Latvijas valsts apmaksātos pakalpojumus vai Eiropas veselības apdrošināšanas karti (EVAK). Ekstrapolējot uz visu PMLP registrēto ārvalstīs dzīvojošo Latvijas valstspiederīgo skaitu, medicīnisko aprūpi par valsts 
līdzekliem vai ar EVAK karti pēdējo piecu gadu laikā varētu būt saṇēmušas aptuveni 709 personas no visiem 3378 ārvalstīs mītošajiem Latvijas valstspiederīgajiem ${ }^{11}$, kuri ir izmantojuši Latvijas veselības aprūpes iespējas ${ }^{12}$. Pārējie ir maksājuši paši vai pakalpojumus apmaksājuši dažādi apdrošināšanas veidi.

\section{Noslēgums}

Pētījuma rezultāti lauj secināt, ka ir noteikti diasporas segmenti, kam Latvijas

11 Aprēḳināts kā $1,5 \%$ no $225 \quad 198$ PLMP datubāzē reǵistrēto ārvalstīs mîtošo Latvijas valstspiederīgo skaita, kas reizināts ar 21 .

${ }^{12}$ Nav datu par vairākkārtēju veselības aprūpes pakalpojumu saṇemšanu. veselības aprūpes sistēma varētu šḳist pieejamāka gan praktiski, gan finansiāli, turklāt ir ērtāka arī komunikatīvā un sociokulturālā ziņā, un to apliecina gan statistikas, gan intervijās aptaujāto dati. Tostarp aptaujas rezultāti liecina, ka ir maz respondentu, kuri būtu neapmierināti ar invaliditātes un paliatīvo aprūpi mītnes zemēs. G̦eogrāfiskais attālums ir mazāk svarīgs Eiropas robežās, lai saṇemtu veselības aprūpi Latvijā. Kā liecina pētījuma rezultāti, iespējas veikt profilaktiskās apskates, saņemt speciālista un ǵimenes ārsta konsultācijas gan veido ciešu saikni ar Latviju kā izcelsmes valsti, gan veicina transnacionālu dzīvesveidu. Neraugoties uz atsevišķu izceḷotāju grupu noraidošo attieksmi pret Latvijas valsti, kopumā ir vērojama uzticēšanās veselības aprūpes sektoram Latvijā.

\section{VĒRES}

Chander, A. (2001) Diaspora Bonds. New York University Law Review, 76.

Directive 2011/24/EU of the European Parliament and of the Council of 9 March 2011 on the application of patients' rights in cross-border healthcare. Latviski pieejams: https://ec.europa.eu/health/cross_border_careloverview_lv (30.09.2020.).

Dzenovska, D. (2012) Aizbraukšana un tukšums Latvijas laukos. Rīga : Biznesa augstskola Turība.

Goldmanis, M. (2015) Statistisko svaru dizains pētījumā Latvijas emigrantu kopienas. Mierina, I. (sast.) Latvijas emigrantu kopienas: cerību diaspora. Rīga : LU Filozofijas un socioloǵijas institūts.

Hazans, M. (2016) Atgriešanās Latvijā: remigrantu aptaujas rezultāti. Rīga : LU Diasporas un migrācijas pētījumu centrs. https://www.diaspora.lu.lv/fileadmin/user upload/lu portal/projekti/diaspora/petijumi/ Atgriesanas_Latvija_-_petijuma_zinojums.pdf(30.09.2020.).

Mieriņa, I. (2019) Kas mudina aizbraucējus atgriezties Latvijā: vai tikai ienākumu jautājums? Rīga : LU Diasporas un migrācijas pētījumu centrs. Pieejams: https://www.pkc.gov.lv/sites/default/files/inline-files/ NAP\%20prezentacija\%20MIerina.pdf (30.09.2020.).

Pilsonības un migrācijas lietu pārvalde (PMLP) (2020) Latvijas valstspiederīgo personu skaits ārvalstīs (01.01.2020.). Piejams: https://www.pmlp.gov.lv/lv/assets/PSAV_Aarvalstiis_Latvijas_VPD_2020.pdf (30.09.2020.).

Reine, I. (2020) Sociālās un veselības aprūpes līkloči: transnacionālisma izpausmes iespēju laikmetā. Referāts LU 78. starptautiskās zinātniskās konferences sesijā "Jaunās migrācijas formas: ko tās nozīmē migrācijas pētniecībai”. Rīga : LU Filozofijas un socioloǵijas institūts. 